\title{
Effects of pressure control and pressure support ventilation on ventilator induced lung injury in experimental acute respiratory distress syndrome with intra-abdominal hypertension
}

\author{
CL Santos ${ }^{1,2^{*}}$, RS Santos ${ }^{1}$, L Moraes $^{1}$, CS Samary ${ }^{1}$, NS Felix ${ }^{1}$, PL Fiorio Júnior ${ }^{3,4}$, MM Morales $^{1}$, MG Abreu ${ }^{5}$, P Pelosi ${ }^{6}$, \\ A Schanaider ${ }^{2}$, PL Silva', PRM Rocco ${ }^{1}$
}

From ESICM LIVES 2015

Berlin, Germany. 3-7 October 2015

\begin{abstract}
Introduction
In acute respiratory distress syndrome (ARDS), intraabdominal hypertension (IAH) increases intra-thoracic pressures, leading atelectasis and deterioration of respiratory mechanics and gas-exchange. The optimal setting of mechanical ventilation (MV) and its impact on respiratory function and ventilator-induced lung injury (VILI) in ARDS associated with IAH needs to be better clarified. Lung-protective $\mathrm{MV}$ with low tidal volume $\left(\mathrm{V}_{\mathrm{T}}\right)$ and positive end-expiratory pressure (PEEP) has been recommended; however, assisted MV may be a favorable alternative to controlled MV at the early phase of ARDS, since it requires less sedation, no paralysis and is associated with better lung protection, reducing the risk of VILI. We hypothesized that pressure-support ventilation (PSV) improve pulmonary morphofunction and minimize lung injury in ARDS with IAH.
\end{abstract}

\section{Objectives}

To compare the effects of PSV with protective MV (PCV) on arterial blood gases, lung mechanics and histology, as well as to identify biological markers of inflammation and fibrogenesis in a model of ARDS with IAH.

\section{Methods}

24. Wistar rats (250-300 g) were submitted to the a sequence of events: 1) receive Escherichia coli lipopolysaccharide (LPS) intraperitoneally $(1,000 \mu \mathrm{g}) ; 2)$ waiting

${ }^{1}$ Federal University of Rio de Janeiro, Laboratory of Pulmonary Investigation, Rio de Janeiro, Brazil

Full list of author information is available at the end of the article period of 24 hours for development of ARDS; 3) anesthesia and mechanical ventilation; 4) induction of IAH (15 mmHg) or not; 5) random assignment to PCV $\left(\mathrm{V}_{\mathrm{T}}=6 \mathrm{~mL} / \mathrm{kg}\right.$, respiratory rate $(\mathrm{RR})=80$ breaths $/ \mathrm{min}$, fraction of inspired oxygen $\left(\mathrm{FIO}_{2}\right)=0.4$ and PEEP $=5$ $\mathrm{cmH}_{2} \mathrm{O}$ ) or PSV. During PCV, animals were paralyzed with pancuronium bromide. In PCV and PSV, the driving pressure was adjusted to achieve $\mathrm{V}_{\mathrm{T}}=6 \mathrm{ml} / \mathrm{kg}$. In addition, in PCV, the RR was controlled to keep minute ventilation constant $(160 \mathrm{ml} / \mathrm{min})$. Peak (Ppeak,RS), and mean (Pmean, ${ }_{\mathrm{RS}}$ ) airway pressures and arterial blood gases were analyzed at baseline and at the end of $1 \mathrm{~h}$ ventilation. Lungs were removed for lung histology and molecular biology analysis [mRNA expression of interleukin (IL)-6, and pro-collagen type III (PCIII)].

\section{Results}

PSV improved oxygenation regardless of IAH. In ARDS with IAH, PSV, compared to PCV group, was associated with greater reduction in Ppeak, ${ }_{\mathrm{RS}}$ (PSV: $11.4 \pm 2.4$ $\left.\mathrm{cmH}_{2} \mathrm{O}, \mathrm{PCV}: 16.9 \pm 0.5 \mathrm{cmH}_{2} \mathrm{O}, \mathrm{p}<0.05\right)$ and Pmean, $\mathrm{RS}$ (PSV: $5.8 \pm 1.9 \mathrm{cmH}_{2} \mathrm{O}, \mathrm{PCV}: 9.6 \pm 0.2 \mathrm{cmH}_{2} \mathrm{O}, \mathrm{p}<0.05$ ). Furthermore, PSV reduced the amount of alveolar collapse, and the mRNA expression of interleukin (IL)- 6 and type III procollagen compared to PCV.

\section{Conclusions}

In this model of ARDS with IAH, PSV, compared to $\mathrm{PCV}$, promoted functional and lung morphological benefit thus mitigating VILI. 


\section{Grant Acknowledgment \\ CNPq, FAPERJ, CAPES, PRONEX, INCT-INOFAR.}

\section{Authors' details}

${ }^{1}$ Federal University of Rio de Janeiro, Laboratory of Pulmonary Investigation, Rio de Janeiro, Brazil. ${ }^{2}$ Federal University of Rio de Janeiro, Department of Surgery, Faculty of Medicine, Rio de Janeiro, Brazil. ${ }^{3} D^{\prime}$ Or Institute for Research and Education, Hospital Copa D'Or, Rio de Janeiro, Brazil. ${ }^{4} D^{\prime}$ Or Institute for Research and Education, Hospital Caxias D'Or, Duque de Caxias, Brazil. ${ }^{5}$ Dresden University of Technology, Department of Anesthesiology, Dresden, Germany. ${ }^{6}$ University of Genoa, Department of Surgical Sciences and Integrated Diagnostics, Genoa, Italy.

Published: 1 October 2015

\section{References}

1. Rocco PR, Pelosi P: Pulmonary and extrapulmonary acute respiratory distress syndrome: myth or reality? Curr Opin Crit Care 2008, 14:50-55.

2. Quintel $M$, Pelosi $P$, Caironi $P$, et al: An increase of abdominal pressure increases pulmonary edema in oleic acid-induced lung injury. Am J Respir Crit Care Med 2004, 169:534-541.

doi:10.1186/2197-425X-3-S1-A806

Cite this article as: Santos et al:: Effects of pressure control and pressure support ventilation on ventilator induced lung injury in experimental acute respiratory distress syndrome with intra-abdominal hypertension. Intensive Care Medicine Experimental 2015 3(Suppl 1):A806.

\section{Submit your manuscript to a SpringerOpen ${ }^{\circ}$ journal and benefit from:}

- Convenient online submission

- Rigorous peer review

- Immediate publication on acceptance

- Open access: articles freely available online

- High visibility within the field

- Retaining the copyright to your article 